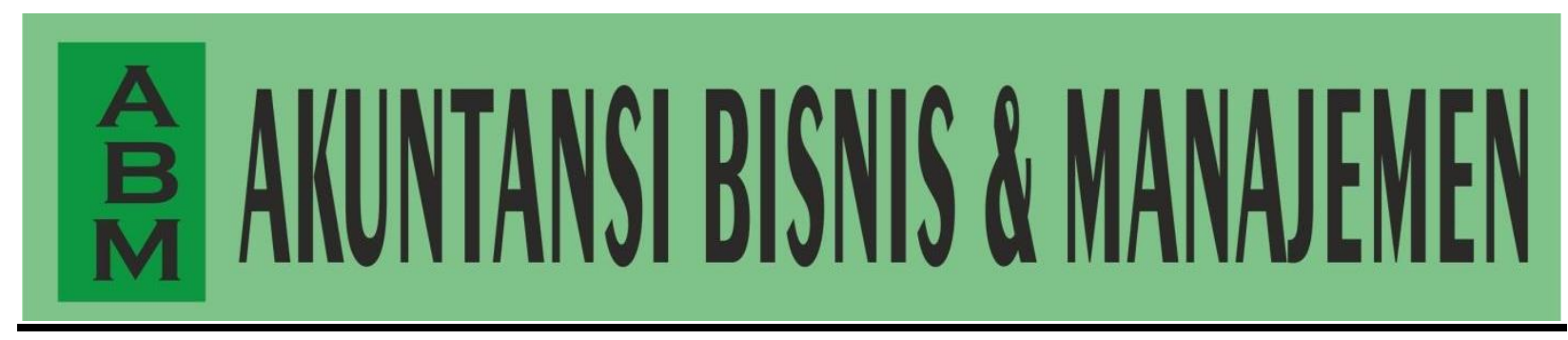

\title{
PENGARUH PEMAKNAAN KERJA, INSENTIF DAN SISTEM PEMBAYARAN TERHADAP KINERJA MELALUI KEPUASAN KERJA
}

\author{
Adi Pramono1), Sonhaji ${ }^{2)}$, Tachjudin ${ }^{3)}$ \\ STIE Malangkuçeçwara
}

STIE Malangkuçeçwara (Malangkuçeçwara School of Economics)

Jalan Terusan Candi Kalasan, Malang, Jatim

E-Mail: sonhaji60@gmail.com

DOI: https://doi.org/10.35606/jabm.v28i1.809

\section{Akuntansi Bisnis dan \\ Manajemen (ABM),}

Vol. 28

No. 01

Halaman 34-44

Bulan April, Tahun 2021

ISSN 0854-4190

E-ISSN 2685-3965

Informasi Artikel

Tanggal Masuk:

01 November 2020

Tanggal Revisi:

31 Maret 2021

Tanggal Diterima:

06 April 2021

\section{Abstract}

This study aims to determine the effect of job meaning, incentives and payment systems on performance through job satisfaction. The research sample was 85 employees in Pasuruan Regency, East Java. Data were collected through a questionnaire and analyzed using path analysis. This study found that the meaning of work and the payment system affect employee job satisfaction, while incentives are not proven to have an effect. Furthermore, job satisfaction is not proven to affect performance.

Keywords: meaning of work; incentive; payment system; job satisfaction; employee performance

\section{Abstrak}

Penelitian ini bertujuan untuk mengetahui pengaruh pemaknaan kerja, insentif dan sistem pembayaran terhadap kinerja melalui kepuasan kerja. Sampel penelitian sebanyak 85 perangkat desa di Kabupaten Pasuruan Jawa Timur. Data dikumpulkan melalui kuesioner dan dianalisis dengan menggunakan analisis jalur. Penelitian ini menemukan bahwa pemaknaan kerja dan sistem pembayaran memengaruhi kepuasan kerja perangkat desa sedangkan insentif tidak terbukti berpengaruh. Selanjutnya kepuasan kerja tidak terbukti memengaruhi kinerja.

Keywords: pemaknaan kerja; insentif; sistem pembayaran; kepuasan kerja 


\section{PENDAHULUAN}

Operasional organisasi akan berjalan lancar dan tujuannya dapat dicapai jika di dalamnya terdapat sumber daya manusia (SDM) atau karyawan yang memiliki kemauan untuk selalu meningkatkan kinerjanya. Peningkatan ini akan selalu diusahakan oleh karyawan melalui pengerjaan tugas yang sesuai dengan deskripsi tanggung jawabnya, bahkan lebih dari yang diharapkan. Tentu saja banyak faktor yang menyebabkan kinerja karyawan tercapai. Namun, faktor pengaruh yang dominan umumnya hanya ada beberapa, yang dapat ditelusuri dari sisi internal dan eksternal karyawan. Faktor-faktor dimaksud diantaranya adalah pemaknaan kerja (Wahyuni, 2017), sistem pembayaran (Soetisna et al., 2015), insentif (Candrawati et al., 2013) dan kepuasan kerja (Wardiana et al., 2017). Faktor-faktor tersebut yang diusahakan untuk diketahui dalam penelitian ini, khususnya terkait dengan Perangkat Desa (PD).

Dalam perkembangannya, Pemerintah Desa mengalami dinamika. Hal ini dapat dilihat dari perubahan peraturan pengelolaanya. Undang-Undang Nomor 6 Tahun 2014 tentang Desa, pasal 1 angka 3 menjelaskan dalam menjalankan fungsi pemerintahan Kepala Desa dibantu oleh Perangkat Desa yang diatur dalam pasal 4853. Dalam Undang-Undang Nomor 5 Tahun 1979 tentang Pemerintahan Desa, Perangkat Desa hanya Sekretaris Desa dan Kepala-Kepala Dusun. Sedangkan dalam Undang-Undang Nomor 32 Tahun 2004, pasal 202 dijelaskan bahwa Pemerintahan Desa terdiri atas Kepala Desa dan Perangkat Desa. Perangkat Desa terdiri atas Sekretaris Desa, pelaksana teknis lapangan, seperti Kepala Urusan, dan unsur kewilayahan seperti Kepala Dusun atau dengan sebutan lain. Struktur yang belakangan adalah untuk merespon perubahan lingkungan (RI, 1979, 2004, 2014). Sebagi unsur Pemerintahan Desa, tentu saja PD memiliki posisi yang strategis karena berhubungan langsung dengan masyarakat yang terkadang menuntut harapan yang tinggi pada kinerja pelaksana pelayanan publik. Tugas pemerintah desa adalah memberikan pelayanan publik yang mampu memuaskan masyarakat.

Tugas tersebut mengarah pada tuntutan PD yang profesional, efektif, efisien, dan akuntabel, yang harus diimbingi dengan perhatian pada faktor-faktor yang membuat mereka bekerja secara memadai. Faktor-faktor yang ada pada PD inilah yang menarik untuk diteliti. Beberapa telah dilakukan oleh Fauza et al. (2014), Lewin (2003) dan Sulistyani \& Irawan (2018). Kinerja seorang pegawai atau pelaksana tugas, tentu saja ini termasuk kinerja PD, dapat dipengaruhi oleh beberapa faktor yang dapat dikelompokkan ke dalam faktor internal dan eksternal. Faktor internal dapat meliputi; niat dan motivasi pribadinya, makna bekerja yang diyakini, pemahaman terhadap tugas dan fungsinya, serta anggapan seberapa jauh kebutuhan pribadinya terpenuhi dari pekerjaannya. Sedangkan faktor eksternal dapat terdiri atas; gaji beserta sistemnya, tuntutan kebutuhan hidup, sistem kerja dan lingkungannya (Sasongko et al., 2017; Suryaningtyas et al., 2014).

Penelitian ini tidak secara spesifik menyebut faktor internal dan eksternal yang memengaruhi kinerja, namun lebih pada memilih variabel-variabel yang termasuk dalam aspek internal dan eksternal. Dengan demikian, aspek internal dan eksternal merupakan pengelompokan guna memudahkan pemahaman dan pemetaan faktorfaktor. Pada pendahuluan ini, selain menyinggung pengamatan pendahuluan, peneliti akan mengulas variabel-variabel penelitian sebelumnya yang menunjukkan aspek- 
aspek terkait kinerja yang selanjutnya disusun rerangka hubungan dalam penelitian ini untuk melihat pengaruh pemaknaan kerja, sistem pembayaran dan insentif terhadap Kinerja melalui Kepuasan Kerja PD.

Pengamatan pendahuluan terhadap PD menjadikan peneliti tertarik untuk menganalisis lebih lanjut hal-hal yang memengaruhi kinerja PD, diantaranya meliputi pemaknaan kerja, sistem pembayaran, insentif dan kepuasan kerja. Pola kaitan antara variabel-variabel tersebut tentu saja perlu diteliti lebih lanjut guna menguji model hubungannya. Sebagai bagian dari sumber daya manusia, PD memiliki sifat unik dan menarik untuk diteliti. Ditinjau dari hal yang penting bagi diri PD yaitu imbalan. Selain itu Rivai \& Sagala (2011) berpendapat bahwa kepuasan pegawai dalam pekerjaannya akan meningkatkan produktivitas kerja yang disebabkan oleh pemberian insentif atau kompensasi kepada pegawai yang wajar dan adil. Hal senada seperti yang dikemukakan oleh Mangkunegara, (2013) bahwa insentif atau kompensasi yang diterima pegawai sangat berpengaruh pada tingkat kepuasan kerja, motivasi kerja dan hasil kerja. Variabel-variabel tersebut penting untuk diteliti untuk melihat konsistensi hubungannya pada sumber daya manusia tertentu yaitu PD terkait dengan kinerja.

Kinerja merupakan hal penting baik bagi individu maupun bagi organisasi. Kumpulan kinerja dari setiap individu yang ada di dalam organisasi akan menjadi kinerja organisasi keseluruhan. Karenanya peningkatan kinerja individu atau pegawai memicu pada pencarian penjelasan faktor-faktor apa yang memengaruhi kinerja pegawai. Faktor pegawai dapat dilihat dari dua sudut pandang, yaitu dari internal, sesuatu yang ada di dalam diri manusia, dan eksternal, yang berada di luar manusia. Informasi faktor-faktor tersebut dapat digunakan untuk mengetahui implikasinya pada kinerja pegawai. Pengelompokkan dan pengidentifikasian variabel-variabel internal dan eksternal akan memudahkan mengetahui penyebab kinerja pegawai (Rivai \& Sagala, 2011, pp. 102-104). Kinerja pegawai juga dapat dilihat dari motivasi dan tujuan yang bersangkutan. Hal ini wajar karena kekuatan motivasi akan menentukan penggapaian tujuan. Selain itu pemaknaan tujuan akan berimbas pada pemaknaan tugas dan pelaksanaannya. Motivasi internal yang kuat akan berpengaruh pada kinerja jika terdapat faktor eksternal yang dapat mendorong kinerja pegawai (Nawawi, 2005, p. 259), seperti gaji dan sistem pembayaran yang dapat memengaruhi kinerja pegawai. Namun ini bukan satu-satunya faktor, pandangan pegawai terhadap pekerjaan itu sendiri juga dapat memengaruhi kinerja.

Pemaknaan kerja bagi seorang pegawai berhubungan dengan hal-hal yang terkait dengan pekerjaan itu sendiri, seperti kepuasan kerja yang berujung pada kinerja. Apa pun yang bermakna bagi seseorang akan memberikan kepuasan pada pemiliknya. Oleh karena itu, pemaknaan kerja ini telah menjadi kajian penelitian yang telah lama dilakukan. Hal ini wajar karena pemaknaan kerja memiliki arti penting baik bagi pegawai maupun organisasi dengan masing-masing perspektif yang berbeda. Pemaknaan Kerja secara arti memiliki tiga dimensi pengertian, yang pertama dari dimensi pentingnya sebuah pekerjaan, yang berarti nilai pekerjaan menurut seseorang. Dimensi kedua adalah arah dan orientasi seseorang terhadap pekerjaannya, yang menggambarkan sesuatu yang dicari dan tujuan yang memandu tindakannya. Ketiga, pengaruh koherensi antara harapan seseorang, nilai-nilai, dan tindakannya di lingkungan kerjanya (Morin, 2008, p. 4). Pandangan tersebut setidaknya memuat 
aspek-aspek, seperti nilai, orientasi. harapan dan tindakan. Ditinjau dari faktor-faktor tersebut dapat diperkirakan bahwa Pemaknaan Kerja akan memengaruhi Kepuasan Kerja, karena seseorang atau pegawai akan puas jika nilai-nilai, orientasi dan harapannya terpenuhi.

Sebuah proyek penelitian pada area kesehatan psikologis berkaitan dengan makna kerja, kesehatan mental dan komitmen organisasi yang dilakukan oleh Morin (2008) mengungkapkan bahwa seseorang cenderung mencari pekerjaan yang memungkinkan dirinya merasa berguna. Ini tentu saja berhubungan dengan pemaknaan kerja bagi yang bersangkutan. Lebih lanjut laporan tersebut menjelaskan bahwa pekerjaan adalah bermakna ketika dilakukan dengan tanggung jawab, yang tidak hanya menyangkut pelaksanaannya, tetapi juga meliputi hasil dan konsekuensinya. Pekerjaan dianggap bermakna jika memberikan kesenangan kepada yang melakukannya. Yang melakukan memeroleh kepuasan dari pekerjaan yang dianggap bermakna tersebut yang pada akhirnya dia dapat mencapai tujuannya secara efektif. Walau tidak tertuju langsung pada kepuasan, Wahyuni, (2017) telah berhasil membuktikan bahwa makna atau pemaknaan kerja berhubungan dengan Work Engagement yang juga menggambarkan rasa puas yang tampak pada adanya semangat, konsentrasi dan pelaksanaan pekerjaan dengan sungguh-sungguh. Dugaan bahwa pemaknaan kerja memengaruhi kepuasan kerja yang pada akhirnya akan memengaruhi kinerja perlu untuk dibuktikan.

Penelitian pendahuluan dilakukan melalui pengamatan fenomena di Kecamatan Pandaan, Kabupaten Pasuruan, Jawa Timur (selanjutnya disebut Pandaan), tempat penelitian ini dilakukan. Hasil pengamatan, masih terdapat penggunaan waktu PD untuk mencari tambahan penghasilan guna memenuhi kebutuhan hidupnya. Fenomena ini menarik untuk diteliti lebih lanjut untuk membuktikan implikasi pada kinerja PD. Adakah penurunan kinerja karena terdapat keengganan melaksanakan tugasnya dan penggunaan waktu untuk mencari kompensasi tambahan. Pengamatan pendahuluan dilakukan guna mencari informasi awal yang diperlukan untuk menggali informasi lebih mendalam mengenai perilaku PD serta sikap mereka, yang salah satunya terhadap pembayaran Penghasilan Tetap (SilTap).

PD sebagai salah satu struktur pemerintahan Indonesia, penghasilannya diatur dalam Peraturan Pemerintah Nomor 72 Tahun 2005 tentang Desa. Dalam pasal 27 Peraturan Pemerintah ini diatur bahwa: (i) Kepala Desa dan Perangkat Desa diberikan penghasilan tetap setiap bulan dan/atau tunjangan lainnya sesuai dengan kemampuan keuangan Desa; (ii) Penghasilan tetap dan/atau tunjangan lainnya yang diterima Kepala Desa dan Perangkat Desa ditetapkan setiap tahun dalam Anggaran Pendapatan dan Belanja Desa (APB Desa); dan Penghasilan tetap tersebut paling sedikit sama dengan Upah Minimum Regional Kabupaten/Kota (RI, 2005). Inilah bentuk kompensasi bagi perangkat desa yang merupakan penghasilan bagi PD. Penghasilan Perangkat Desa dalam bentuk SilTap yang bersumber dari Dana Perimbangan dalam APBN yang diterima kabupaten/kota dan dibayarkan setiap bulan, yang rinciannya sesuai dengan Undang-Undang dan Peraturan Pemerintah. Dalam Peraturan Pemerintah No. 43 Tahun 2014 diatur SilTap Kepala Desa (Kades) dan Perangkat Desa, pembayaran dilakukan setiap bulannya (RI, 2014). Pembayaran SilTap dilakukan dengan bersumber dari APB Desa dan berada di pos keuangan Alokasi Dana Desa (ADD). Berdasarkan Pasal 81 Peraturan Pemerintah No. 43 tahun 2014 serta Peraturan 
Pemerintah No. 47 tahun 2015, SilTap merupakan Penghasilan tetap Kepala Desa dan Perangkat Desa yang dianggarkan dalam APB yang bersumber dari ADD Desa.

Hampir bisa dipastikan bahwa individu bekerja untuk suatu imbalan, utamanya dalam bentuk materi yang dapat disebut upah, gaji, bonus, kompensasi dan insentif. Variabel ini dianalisis dalam penelitian ini karena merupakan harapan PD sebagai jumlah yang dapat dibawa pulang oleh PD. Menurut peneliti, variabel ini lebih menggambarkan keinginan dan kepuasan. Seberapa yang dapat diperoleh seorang individu dalam bekerja akan memengaruhi kinerjanya. Ini telah dibuktikan bahwa kompensasi dan lingkungan kerja berpengaruh terhadap motivasi yang selanjutnya memiliki pengaruh terhadap prestasi kerja (Wuryani, 2009). Sedangkan pengaruh antara gaji, kompensasi dan insentif dengan kinerja karyawan juga telah dibuktikan (Batilmurik, 2010; Candrawati et al., 2013; Danish \& Usman, 2010; Fitriadi, 2015). Haryono (2009) membuktikan bahwa Karakteristik Pekerjaan berpengaruh terhadap Kinerja dan kompensasi/gaji berpengaruh terhadap kinerja dengan motivasi sebagai variabel intervening. Sedangkan Handayaningrum et al. (2016) menemukan bahwa terdapat pengaruh kompensasi, lingkungan kerja dan karakteristik pekerjaan terhadap kepuasan kerja dan kepuasan kerja berpengaruh signifikan dan positif terhadap kinerja karyawan. Dengan demikian dapat diduga bahwa insentif memengaruhi kepuasan kerja dan kinerja.

Sepanjang pengetahuan peneliti belum banyak penelitian yang secara spesifik membahas pembayaran SilTap terkait dengan kinerja PD. Ini bersifat administratif, atau sistem pembayaran. Pandangan PD terhadap sistem ini perlu dianalisis untuk mengetahui dampaknya terhadap kepuasan kerja dan selanjutnya ke kinerja. Menurut peneliti, PD memandang SilTap sebagai suatu cara pembayaran yang menggambarkan kapan gaji diterima dan berapa kali dibayarkan dalam satu tahun. PD hanya perhatian terhadap apakah gajinya dibayar tepat waktu atau tidak. Karena jika terlambat, PD akan mencari kompensasi di hal lain, seperti mencari pinjaman. Ketepatan pembayaran menjadi perhatian utama dari PD. Jadi ini adalah bentuk terpenuhinya harapan dari PD terhadap sistem pembayaran. Terdapat penelitian yang dapat menggambarkan hubungan antara sistem pembayaran terhadap PD dengan kepuasan kerja, yaitu dilakukan oleh Soetisna et al. (2015) tentang pengaruh sistem remunerasi dengan kepuasan kerja dan kinerja. Peneliti tersebut menunjukkan bahwa terdapat hubungan antar sistem remunerasi dengan kepuasan kerja. Jadi dapat diduga bahwa sistem pembayaran memengaruhi kepuasan kerja pegawai.

Kinerja bukanlah suatu yang dipengaruhi oleh faktor tunggal. Sebagai ukuran keberhasilan baik bagi individu maupun ukuran keberhasilan pengelola, kinerja pegawai dipengaruhi oleh kombinasi dari beberapa faktor. Selain variabel yang sudah disinggung pada pembahasan sebelumnya, terdapat variabel yang berpengaruh kuat pada kinerja pegawai, yaitu kepuasan kerja. Ini dibuktikan oleh Pushpakumari (2008) dan Nasution et al. (2018). Dengan menganalisis dengan variabel-variabel lain, diantaranya Motivasi, Lingkungan Kerja, Kompetensi Dan Kompensasi, Dhermawan et al. (2012) juga membuktikan pengaruh antara Kepuasan Kerja Dan Kinerja. Sehubungan dengan penelitian ini, dapat diduga bahwa kepuasan kerja memengaruhi kinerja pegawai. 
Informasi awal yang peneliti temukan adalah bahwasanya terdapat beberapa PD terkesan enggan melaksanakan tugasnya dengan baik, seperti mangkir dari tugas, kurang disiplin dalam bekerja, dan tidak fokus pada tugas. Perilaku tersebut menurut peneliti dapat diartikan sebagai bentuk ketidakpuasan mereka dalam bekerja. Namun hal ini perlu dibuktikan lebih lanjut dalam analisis yang mendalam. Fenomena tersebut memunculkan gagasan penelitian untuk mengetahui faktor-faktor yang memengaruhi kinerja dengan melihat dari kepuasan kerja. Ini dilakukan karena bisa jadi keengganan melaksanakan tugas dari karyawan karena tidak adanya kepuasan kerja. Yang menarik untuk dilihat juga adalah faktor-faktor apa yang memengaruhi kepuasan kerja ini. Kalau memang kepuasan kerja memiliki pengaruh kepada kinerja, tentu faktor yang memengaruhi kepuasan kerja perlu untuk dianalisis dan dibuktikan. Inilah yang ingin diketahui dalam penelitian ini. Pengamatan awal dan kajian beberapa penelitian sebelumnya berhubungan dengan aspek-aspek kinerja. Dari uraian di atas, selanjutnya dapat disusun rerangka hubungan variabel dalam penelitian ini yang menggambarkan pengaruh pemaknaan kerja, sistem pembayaran dan insentif terhadap Kinerja melalui Kepuasan Kerja PD. Jika digambarkan akan tampak sebagai berikut.

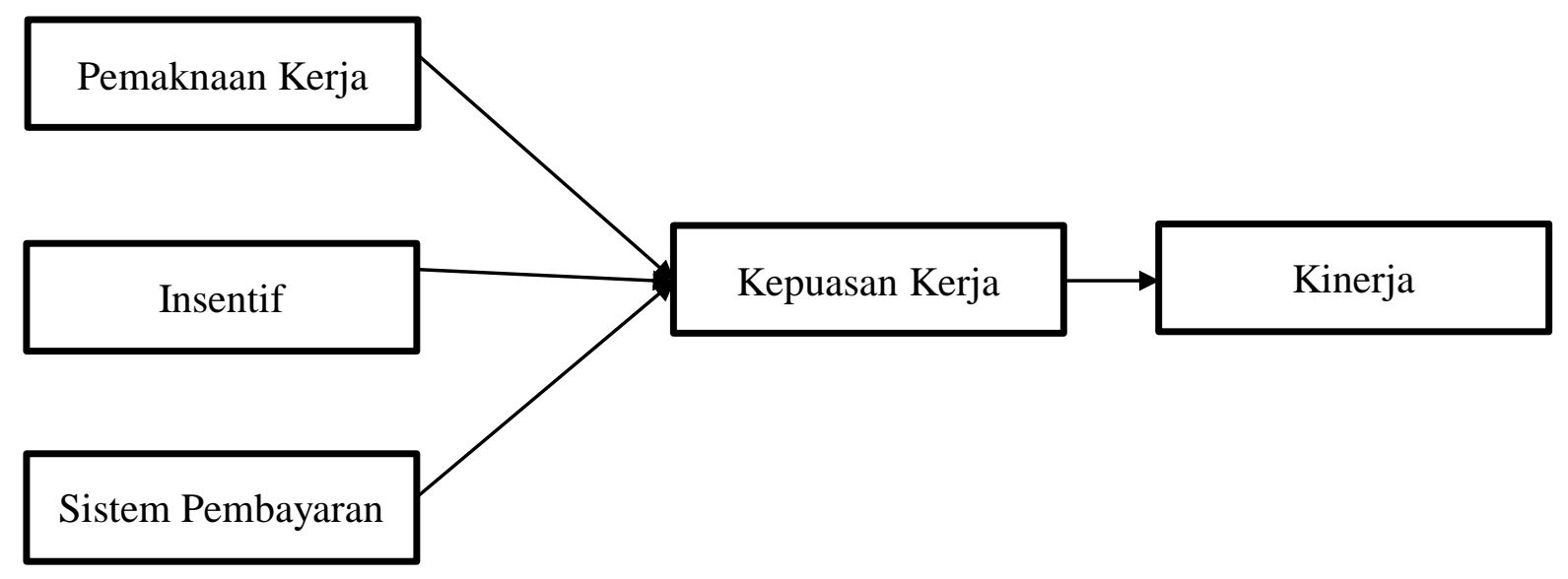

Gambar 1. Model penelitian

\section{METODE PENELITIAN}

Penelitian ini merupakan penelitian eksplanatori, yang berusaha menjelaskan hubungan sebab akibat diantara variabel yang diuji. Penelitian ini menguji hubungan antara pemaknaan kerja, insentif dan sistem pembayaran dengan kepuasan kerja. Selanjutnya menganalisis hubungan kepuasan kerja dengan kinerja. Hubungan ini untuk membuktikan bahwa pemaknaan kerja, insentif dan sistem pembayaran berhubungan dengan kinerja melalui kepuasan kerja. Hubungan sebab akibat antar variabel tersebut akan dapat membangun sebuah konstruksi konseptual mengenai kepuasan kerja dan kinerja PD.

Penelitian ini dilakukan pada PD di Kecamatan Pandaan, Kabupaten Pasuruan, Jawa Timur. Jumlah populasi sebanyak 119 orang dengan perincian 10 orang Kepala Desa, 10 orang Sekretaris Desa, 30 orang Kaur Desa dan 69 orang Kepala Dusun. Adapun sampel penelitian ini dipilih dengan menggunakan teknik Purposive Sampling, yaitu responden dipilih dengan pertimbangan sesuai kebutuhan penelitian (Sugiyono, 2011). Dalam penelitian ini, perangkat desa yang memenuhi kriteria sebanyak 85 .

Data dikumpulkan dengan menggunakan kuesioner. Kuesioner yang diberikan kepada responden berisi daftar pertanyaan mengenai pemaknaan kerja, intensif, sistem pembayaran, 
kepuasan kerja dan kinerja. Kuesioner disusun berdasarkan indikator variabel dalam bentuk pertanyaan-pertanyaan yang relevan. Pertanyaan-pertanyaan tersebut dapat dijawab oleh responden dengan mengisikan skor nilai antara 1- 5. Analisis data yang dilakukan dalam penelitian ini adalah analisis jalur. Hal ini didasarkan pada rerangka konseptual yang telah dibangun sebelumnya dimana variabel-variabel penelitian memiliki alur pengaruhnya masingmasing. Rerangka konseptual tersebut menggambarkan pengaruh pemaknaan kerja, intensif dan sistem pembayaran yang berpengaruh pada kinerja melalui kepuasan kerja.

\section{HASIL DAN PEMBAHASAN}

Hasil pengujian secara statistik dengan analisis jalur tampak dalam Tabel 1 yang menggambarkan bahwa pemaknaan kerja dan sistem pembayaran mempunyai pengaruh positif signifikan terhadap kepuasan kerja sedangkan pemberian insentif tidak berpengaruh terhadap kepuasan kerja. Sedangkan variabel kepuasan kerja tidak berpengaruh signifikan terhadap kinerja. Hasil analisis ini menarik untuk diulas karena insentif sebagaimana lazimnya membuat orang merasa puas atas kerjanya justru tidak dapat membuktikan pengaruhnya pada kepuasan kerja PD. Bukan itu saja, kepuasan kerja juga tidak memberikan pengaruh pada kinerja PD.

Tabel 1. Koefisien Jalur

\begin{tabular}{llcrrrrrr}
\hline $\begin{array}{c}\text { Hipo- } \\
\text { tesis }\end{array}$ & $\begin{array}{c}\text { Pola } \\
\text { Hubung- } \\
\text { an }\end{array}$ & $\begin{array}{c}\text { Original } \\
\text { Sample } \\
(\mathbf{O})\end{array}$ & $\begin{array}{c}\text { Sample } \\
\text { Mean } \\
(\mathbf{M})\end{array}$ & $\begin{array}{c}\text { Standard } \\
\text { Deviation } \\
\text { (STDEV) }\end{array}$ & $\begin{array}{c}\text { Standard } \\
\text { Error } \\
\text { (STERR) }\end{array}$ & $\begin{array}{c}\text { T Statistics } \\
(\mid \text { OO/STERR|) }\end{array}$ & $\begin{array}{c}\text { sig } \\
\mathbf{P}\end{array}$ & $\begin{array}{c}\text { Keputusan } \\
\text { Hipotesis }\end{array}$ \\
\hline 1 & PK -> KP & 0.205757 & 0.198233 & 0.06703 & 0.06703 & 3.069621 & 0.00 & accepted \\
2 & IN -> KP & 0.122754 & 0.119509 & 0.208069 & 0.208069 & 0.589966 & 0.56 & reject \\
3 & SP -> KP & 0.34003 & 0.327382 & 0.110415 & 0.110415 & 3.079564 & 0.00 & accepted \\
4 & KP -> KIN & 0.091252 & 0.092917 & 0.133092 & 0.133092 & 0.685628 & 0.50 & reject \\
\hline
\end{tabular}

Dari gambar 1 dan tabel 1 dapat dibuat ulasan analisis sehubungan dengan penelitian ini. Hasil uji secara statistik membuktikan bahwa variabel pemaknaan kerja, sistem pembayaran memengaruhi Kepuasan Kerja PD. Namun variabel insentif tidak memengaruhi kepuasan kerja PD dan variabel kepuasan kerja tidak terbukti berdampak pada kinerja. Hal ini menarik untuk diulas. Hasil tersebut, jika dikaitkan dengan indikator pertanyaan yang peneliti nyatakan di kuesioner, dapat diberi ulasan sehubungan dengan variabel penelitian seperti berikut ini.

Seperti disebutkan sebelumnya bahwa Pemaknaan Kerja memengaruhi Kepuasan Kerja PD. Selama ini PD memandang bahwa pekerjaan adalah hal yang mulia, sebagai amanah dan bernilai ibadah guna memeroleh keridhoan-Nya. PD juga memandang bahwa pekerjaannya menjadikan mereka lebih bermakna sebagai manusia dengan ikut memberikan sumbangsihnya dalam pembangunan desa. Oleh karena itu, PD berusaha memberikan yang terbaik dalam bertugas sesuai dengan fungsinya. Nilai-nilai yang menggambarkan pemaknaan kerja tersebut merupakan hal yang sudah biasa tertanam dalam masyarakat pedesaan yang bersifat religius. Untuk hal ini dapat menjadi kajian penelitian berikutnya yang lebih mendalam.

Variabel yang juga memengaruhi Kepuasan Kerja PD adalah Sistem pembayaran. Temuan ini menarik bagi peneliti karena hal tersebut bertolak belakang dengan fenomena yang peneliti tangkap di awal. Bahwasanya sistem pembayaran yang dilakukan bertahap menimbulkan tenggang waktu yang dalam rangka pemenuhan kebutuhan hidup PD secara ekonomi dapat menimbulkan ketidakpuasan. Fenomena awal ini membawa peneliti pada ide penelitian ini. Dengan hasil uji di atas, menurut peneliti perlu mengaitkan dengan indikator pertanyaan. PD menilai rendah terhadap cara atau sistem pembayaran yang dilakukan setiap bulan, bukan secara 
rapelan. Sepertinya PD lebih perhatian pada jumlah yang diterima dan sementara ini mereka masih dapat mencari solusi pemenuhan kebutuhan di tenggat waktu.

Pemerian berikutnya terkait dengan variabel independen yang tidak memengaruhi variabel dependen. Seperti yang ditunjukkan di hasil uji di tabel 1, bahwa variabel Insentif tidak memengaruhi Kepuasan Kerja PD dan variabel Kepuasan Kerja tidak terbukti memengaruhi kinerja. Temuan ini memang tidak menggambarkan seperti lazimnya sebuah insentif. Hal ini dapat dirunut dari indikator pertanyaan. PD memang merasa bahwa insentif diterima belum dapat membantu memenuhi kebutuhan ekonominya dan tidak terbayangkan di pikirannya menyisihkan untuk ditabung. Dapat dikatakan bahwa Kepuasan Kerja PD ditimbulkan oleh selain insentif. Jadi, Insentif tidak dapat menjelaskan pengaruhya terhadap Kepuasan Kerja PD.

Seperti variabel insentif, Kepuasan Kerja tidak berpengaruh terhadap Kinerja. Ini dapat dikatakan bahwa Kinerja dipengaruhi oleh variabel-variabel lain selain Kepuasan Kerja. Dengan kata lain, Kepuasan Kerja tidak bisa menjelaskan pengaruhnya pada kinerja. Hal ini memang memerlukan pendalaman lebih lanjut untuk mengetahui apakah memang terdapat kepuasan kerja yang rendah, yang walaupun demikian kinerja harus tetap tinggi. Ini juga mengindikasikan perlunya eksplorasi variabel lain atau penelitian lanjutan.

Secara keseluruhan penelitian ini menunjukkan bahwa sebaik apapun seorang PD memahami makna dia bekerja, seyakin apapun dia mampu melaksanakan tugas dan tanggung jawabnya serta seberapa baik sistem pembayaran atas penghasilan yang diterimanya namun ketika besaran insentif yang diberikan tidak sesuai harapan akan berimplikasi pada kepuasannya dalam bekerja dan selanjutnya berdampak pada kinerja.

Konsep mengenai Kepuasan Kerja dan Kinerja yang dikonstruksikan berdasarkan hasil penelitian ini menggambarkan bahwa Pemaknaan kerja, Sistem Pembayaran dan Insentif akan berimplikasi pada Kepuasan Kerja yang selanjutnya akan berdampak pada kinerja PD. Cara PD dalam memaknai pekerjaan yang dilakukannya serta Sistem Pembayaran dan Insentif kepadanya akan berdampak pada Kepuasan Kerjanya. Namun besaran insentif menjadi isu utama dalam penelitian ini dan diduga menjadi penjelas mengapa model teori yang dibangun ada perbedaan temuan dengan penelitian terdahulu. Selain itu menurut peneliti karakteristik responden pedesaan yang religius dapat juga menjadi penjelas. Untuk ini memerlukan penelitian lebih lanjut.

Walaupun Pemaknaan Kerja dan Sistem Pembayaran dapat memengaruhi Kepuasan Kerja yang seharusnya berimplikasi pada kinerja PD, namun perlu dibarengi dengan besaran insentif yang tepat sesuai dengan resiko pekerjaan. Hal ini menurut peneliti dikarenakan besaran insentif yang diharapkan bisa mencukupi kebutuhan hidup. Besaran insentif yang tidak sesuai dengan harapan menjadi alasan untuk mencari penghasilan lain di luar pekerjaan sebagai PD sehingga waktu kerja yang seharusnya digunakan untuk melayani masyarakat menjadi berkurang atau bahkan tidak ada. Hal tersebut menurut peneliti dapat mengganggu kinerja PD dalam melaksanakan tugas dan tanggung jawabnya.

\section{KESIMPULAN}

Kesimpulan yang dapat diambil dalam penelitian ini adalah cara PD dalam memaknai pekerjaannya dan dapat melaksanakan tanggung jawabnya sebagai seorang PD dapat meningkatkan kepuasan kerjanya yang dibarengi dengan sistem pembayaran yang tepat. Temuan lain adalah pemberian insentif seharusnya dilakukan dengan tepat karena besaran insentif akan berdampak pada kepuasan. Jika sebaliknya, insentif tidak akan menimbulkan ketidakpuasan yang selanjutnya berimplikasi pada kinerja jangka panjang. Selain itu, kepuasan kerja yang tidak terpenuhi cenderung akan tidak berimbas pada kinerja.

Sistem pembayaran untuk PD yang baik adalah sistem yang tidak menimbulkan tenggang waktu antara penerimaan penghasilan dengan pengeluaran. Hal tersebut dapat disadari 
bahwasanya PD sebagai manusia juga harus memenuhi kebutuhan hidupnya, terutama yang sudah berumah tangga. Jika terjadi tenggang waktu antara penerimaan penghasilan dengan pengeluaran, maka hal tersebut dapat mendorong mereka untuk memanfaatkan tenggang waktu tersebut untuk mencari penghasilan sehingga berdampak kurang baik pada kinerjanya. Hal ini dikarenakan waktu kerja yang ada digunakan untuk mencari penghasilan sehingga masyarakat kurang terlayani. Seperti yang peneliti kemukakan sebelumnya, bahwa diperlukan eksplorasi penelitian berikutnya yang dapat menjelaskan lebih baik temuan penelitian ini.

\section{IMPLIKASI}

Implikasi dari hal tersebut di atas adalah diperlukan pemahaman yang mendasar bagi seorang PD terhadap jabatan yang disandangnya serta motivasi yang berkelanjutan agar mereka memiliki pemahaman yang baik terhadap pelaksanaan tanggung jawabnya. Selain itu, perlu dipertimbangkan pemberian insentif yang telah berjalan selama ini. Hal ini dikarenakan insentif tersebut justru menimbulkan waktu tenggang bagi PD sehingga menjadi pemicu ketidakpuasan. Perilaku tidak puas karena insentif berdampak tidak baik, walaupun PD masih dapat mencari solusinya. Insentif yang tepat, dapat menjadikan mereka optimal dalam melayani masyarakat sehingga kinerja mereka sebagai PD akan menjadi baik di mata masyarakat. Oleh karenanya, penelitian ini menyarankan adanya kajian untuk menemukan formula insentif yang tepat, terkait dengan jumlah dan masa pembayarannya. Hal ini selain didasari oleh pertimbangan organisasional dan sosial, juga pertimbangan kemanusiaan dimana PD sebagai manusia yang juga memiliki kebutuhan hidup secara ekonomi.

\section{Daftar Pustaka}

Batilmurik, R. W. (2010). Pengaruh Pelatihan dan Kompensasi Terhadap Kepuaan Kerja Karyawan (Studi Pada Hotel Bintang IIIDi Kota Kupang), Tesis. Program Studi MM, Universitas Brawijaya, Malang.

Candrawati, D., Musadieq, M., \& Hakam, M. (2013). Pengaruh Insentif Terhadap Kinerja Karyawan (Studi Pada Karyawan Duta Catering-CV Darma Utama Batu). Jurnal Administrasi Bisnis S1 Universitas Brawijaya, 1(2), 150-157.

Danish, R. Q., \& Usman, A. (2010). Impact of Reward and Recognition on Job Satisfaction and Motivation: An Empirical Study from Pakistan Chairman, Impact of Reward and Recognition on Job Satisfaction and Motivation: An Empirical Study from Pakistan. International Journal of Business and Management, 5(2), 159-167.

Dhermawan, A. A. N. B., Sudibya, I. G. A., \& Utama, I. W. M. (2012). Pengaruh Motivasi, Lingkungan Kerja, Kompetensi, Dan Kompensasi Terhadap Kepuasan Kerja Dan Kinerja Pegawai Di Lingkungan Kantor Dinas Pekerjaan Umum Provinsi Bali. Jurnal Manajemen, Strategi Bisnis, Dan Kewirausahaan, 6(2), 173-184.

Fauza, D. H., Wismantoro, Y., Ekonomi, F., Nuswantoro, U. D., Ekonomi, F., \& Nuswantoro, U. D. (2014). Analisis Faktor-Faktor Yang Mempengaruhi Kinerja Pegawai Negeri Sipil Pada Badan Pertanahan Nasional Kabupaten Boyolali. Media, 22(1), 72-89. http://publikasi.dinus.ac.id/index.php/media/article/view/925/ 695 
Fitriadi, R. (2015). Pengaruh Pemberian Insentif Terhadap Kinerja Karyawan Distributor Baterai Yuasa (Kasus PT. Riau Indotama Abadi Pekanbaru). Jom FISIP, 2(1), 1-9.

Handayaningrum, I., Astuti, E. S., \& Prasetya, A. (2016). Faktor-Faktor Yang Memengaruhi Kepuasan Kerja dan Kinerja Karyawan (Studi pada Karyawan PDAM Kota Malang). Jurnal Administrasi Bisnis (JAB), 40(1), 141-149.

Haryono. (2009). Pengaruh Karakteristik Pekerjaan Dan Kompensasi Terhadap Kinerja Pegawai Dengan Mediasi Motivasi Kerja (Studi Pada Pegawai Badan Pelaksana Penyuluhan Pertanian, Perikanan dan Kehutanan Kabupaten Batang. Program Pascasarjana Magister Manajemen, Universitas Stikubank Semarang.

Lewin, D. (2003). Incentive Compensation in The Public Sector: Evidence and Potential. Journal of Labor Research, XXIV(4), 597-619.

Mangkunegara, A. A. (2013). Manajemen Sumber Daya Manusia Perusahaan. Remaja Rosdakarya.

Morin, E. (2008). The Meaning of Work, Mental Health and Organizational Commitment: Studies and Research Projects. IRSST.

Nasution, E. H., Musnadi, S., \& Faisal. (2018). Faktor-Faktor Yang Mempengaruhi Kepuasan Kerja Dan Dampaknya Terhadap Kinerja Pegawai Kanwil Direktorat Jenderal Kekayaan Negara Aceh. Jurnal Magister Manajemen Fakultas Ekonomi Dan Bisnis Unsyiah, 2(3), 123-134.

Nawawi, H. (2005). Penelitian Terapan. Gajah Mada University Press.

Pushpakumari, M. D. (2008). The Impact of Job Satisfaction on Job Performance :An Empirical Analysis. Forum City, Sri Langka, 9(1), 89-105.

RI. (1979). Undang-Undang Republik Indonesia Nomor 5 Tahun 1979. http://www.bphn.go.id/data/documents/79uu005.pdf

RI. (2004). Undang-Undang Republik Indonesia Nomor 32 Tahun 2004 tentang Otonomi Daerah sebagaimana telah dirubah Undang-Undang Republik Indonesia Nomor 12 Tahun 2008. http://www.dpr.go.id/dokjdih/document/uu/33.pdf

RI. (2005). Peraturan Pemerintah Republik Indonesia Nomor 72 Tahun 2005 Tentang Desa.

RI. (2014). UndangUndang Republik Indonesia Nomor 6 Tahun 2014 tentang Desa. http://www.dpr.go.id/dokjdih/document/uu/UU_2014_6.pdf

Rivai, V., \& Sagala, E. J. (2011). Manajemen Sumber Daya Manusia untuk Perusahaan (2 (ed.)). Rajagrafindo Persada.

Sasongko, N. A., Zaika, Y., \& Suharyanto, A. (2017). Pengaruh Faktor Internal Dan Eksternal Terhadap Kinerja Sumber Daya Manusia Pada Pabrik Kontruksi Beton. Rekayasa Sipil, 11(3), 220-227.

Soetisna, T. W., Ayuningtyas, D., \& Misnaniarti, M. (2015). Penerapan Sistem Remunerasi dan Kinerja Pelayanan. Kesmas: National Public Health Journal, 10(1), 17. https://doi.org/10.21109/kesmas.v10i1.811 
Sugiyono. (2011). Statistika untuk Penelitian. Alfabeta.

Sulistyani, H., \& Irawan, B. (2018). Pengaruh Kompensasi Finansial Terhadap Kinerja Pegawai di Direktorat Serealia Direktorat Jenderal Tanaman Pangan Kementerian Pertanian. In Jurnal Reformasi Administrasi: Jurnal Ilmiah untuk Mewujudkan Masyarakat Madani (Vol. 5, Issue 1).

Suryaningtyas, F. R., Nugraheni, S. A., \& Mawarni, A. (2014). Analisis Faktor Internal dan Faktor Eksternal yang Berhubungan denganKinerja Bidan Desa dalam Kunjungan Neonatal di Kabupaten Pati. Jurnal Manajemen Kesehatan Indonesia. 2(3), 123.131.

Wahyuni, M. (2017). Pengaruh Makna Kerja Dan Occupational Self Efficacy Terhadap Work Engagement Pada Dosen Tetap. Jurnal Psikologi, 10(1), 39-47.

Wardiana, I. P. E., Riana, I. G., \& Sudibya, I. G. A. (2017). Pengaruh Insentif Dan Kepuasan Kerja Terhadap Komitmen Organisasional Dan Motivasi Kerja Karyawan Qnb (Qatar National Bank) Indomesia Area. E-Jurnal Ekonomi Dan Bisnis Universitas Udayana, 12, 4197. https:/ / doi.org/10.24843/eeb.2017.v06.i12.p06

Wuryani, S. (2009). Pengaruh Kompensasi dan Lingkungan Kerja Terhadap Prestasi Kerja Dengan Motivasi Sebagai Mediasi (Studi Pada Satuan Polisi Pamong Praja Provinsi Jawa Tengah). Tesis. Program Pascasarjana. Universitas STIKUBANK. Semarang. 